\title{
Role of Hereditary Factors in Weight Loss and Its Maintenance
}

\author{
V. HAINER ${ }^{1}$, H. ZAMRAZILOVÁ ${ }^{1}$, J. SPÁLOVÁ ${ }^{1}$, I. HAINEROVÁ ${ }^{2}$, M. KUNEŠOVÁ ${ }^{1}$, \\ B. ALDHOON ${ }^{1,3}$, B. BENDLOVÁ ${ }^{1}$
}

${ }^{1}$ Institute of Endocrinology, Prague, Czech Republic, ${ }^{2}$ Department of Paediatrics and Centre for Research of Diabetes, Metabolism and Nutrition, Third Faculty of Medicine, Charles University, Prague, Czech Republic, ${ }^{3}$ Department of Cardiology, Institute for Clinical and Experimental Medicine, Prague, Czech Republic

Received November 12, 2007

Accepted January 17, 2008

On-line February 13, 2008

\section{Summary}

The prevalence of obesity is increasing worldwide at an alarming rate in both developed and developing countries. Obesity is a chronic complex disease of multifactorial origin resulting from a long-term positive energy balance, in which both genetic and environmental factors are involved. Genetically prone individuals are the first to accumulate fat in the present obesogenic environment. Obesity increases the risks of type 2 diabetes, hypertension, cardiovascular disease, dyslipidemia, arthritis, and several cancers and reduces the average life expectancy. Implementation of effective strategies in prevention and management of obesity should become an important target in health care systems. Weight changes throughout life depend on the interaction of behavioral, genetic and environmental factors. Weight loss in response to weight management shows a wide range of interindividual variation which is largely influenced by genetic determinants. The strong control of weight loss by genotype was confirmed by twin and family studies. Recently, special attention has been paid to nutritional, hormonal, psychobehavioral and genetic factors which can predict the response to weight reduction programme. In this article currently available data on the role of obesity candidate gene polymorphisms in weight loss and maintenance are reviewed. It is believed that an elucidation of the genetic component in the prognosis of weight management could assist in the development of more effective and individually tailored therapeutic strategies.

\section{Key words}

Obesity • Genetic factors • Environmental factors • Weight loss • Weight maintenance • Obesity candidate genes • Gene polymorphisms

\section{Corresponding author}

Vojtěch Hainer, Institute of Endocrinology, Národní třída 8, 11694 Prague 1, Czech Republic. E-mail: vhainer@endo.cz

\section{Introduction}

Over the last two decades, obesity prevalence has increased significantly and now represents a major public health problem worldwide in both developed and developing countries (WHO 2000). In many European countries every fourth or fifth adult is obese and about a half of the population is either overweight or obese (Seidell 2002). Obese subjects are becoming more severely obese. The prevalence of body weight excess in 13- and 15 -year-olds is extremely high in the WHO European Region, ranging from $5 \%$ to almost $35 \%$ (WHO 2007). Obesity is a chronic disease of multifactorial origin characterized by enlargement of adipose tissue as a result of positive energy balance. Individual differences in the predisposition to accumulate body fat in response to a positive energy balance appear to be largely genetically determined.

Obesogenic environment and behavior as a cause of the current obesity epidemic

The dramatic increase in the prevalence of obesity over the last two decades cannot be attributed to genetic factors as the human genome is unlikely to have undergone substantial changes over the short period of several decades. On the other hand, our environment and consequently our behavior have undergone crucial changes during this rather short time period. According to Bouchard (2007) both technical conditions (e.g. reliance on the car for transportation, computarization at 
workplace and home, building design, lack of sidewalks, etc.) and social environment (e.g. advertisement, pressure to consume, etc.) have created the current global obesogenic environment which favors the adoption of obesogenic behavior (e.g. high-fat diet, high intake of simple sugars, sedentarism due to low level of habitual physical activity and more time spent by watching TV and sitting at the computer, etc.). Humans and obese persons in particular, have limited ability to oxidize fats regardless of their high intake and thus the excessive amount of fat can be deposited in the adipose tissue almost without limitation.

\section{Role of genetic factors in development of obesity}

The regulation of body weight and energy homeostasis is subject to complex regulatory mechanisms that maintain balance between energy intake, energy expenditure and energy stores. Genetic factors play an important role in this regulation as well as in the development of obesity as shown in animal models and human studies (Bell et al. 2005). Based on the current knowledge of the pathogenesis of obesity the level of involvement of genetic factors in the development of obesity is estimated to be 30-70\% (Comuzzie and Allison 1998, Loos and Bouchard 2003). There is an evidence that suggests four levels of genetic determination of obesity: genetic obesity, strong genetic predisposition, slight genetic predisposition, and genetic resistance (Loos and Bouchard 2003). The last edition of the Human Obesity Gene Map from October 2005 reported more than 600 loci from single-gene mutations in mouse models of obesity, non-syndromic human obesity cases due to single-gene mutations, obesityrelated Mendelian disorders, transgenic and knock-out mice models, QTLs from cross-breeding experiments and genome-wide scans, and genes or markers that have been shown to be associated or linked with an obesity phenotype (Rankinen et al. 2006). The number of studies reporting associations between DNA sequence variation in specific genes and obesity phenotypes has also increased considerably, with 426 findings of positive associations with 127 candidate genes. A promising observation is that 22 genes are each supported by at least five positive studies (Rankinen et al. 2006). If one attributes these genes to particular biological or behavioural traits that may contribute to positive energy balance, five major classes of genotypes can be defined (Bouchard 2007). These classes of genotypes with specific phenotypic characteristics (thrifty, hyperphagic,
Table 1. Five major classes of phenotypes and their relation to genotypes (supported by at least five positive studies).

\begin{tabular}{ll}
\hline Phenotypes & Genotypes \\
\hline Thrifty & ADRB2, ADRB3, UCP1, UCP2, \\
& UCP3 \\
Hyperphagic & $\begin{array}{l}\text { DRD2, HTR2C, LEP, LEPR, } \\
\text { MC4R, NR3C1 }\end{array}$ \\
Sedentary & DRD2, MC4R \\
Low fat oxidizers & ACE, ADIPOQ, GNB3, IL6, INS, \\
Adipogenesis & $\begin{array}{l}\text { LDLR, LIPE, RESISTIN, TNFA } \\
\text { PPARG, VDR }\end{array}$ \\
\hline
\end{tabular}

The Human Obesity Gene Map, Obes. Res. 2006, 14: 529.

sedentary, low fat oxidizing and adipogenic) are shown in Table 1.

During the last years the genetic methods based on chip technology have been exponentially developed. They are more and more often used to hunt for obesity related genes in association genome-wide scans on general populations. These case-control studies now include even more than ten thousand probands. One of the most interesting findings from this year is the discovery of very strong association of several polymorphisms of fat mass and obesity associated gene (FTO) with BMI and with the predisposition to childhood and adult obesity. Wellcome Trust Case Control Consortium (WTCCC) examined 13 cohorts counting 38,759 participants and there was shown that the SNP rs9939609 is reproducibly associated with BMI in white European populations (Frayling et al. 2007). Other two independent studies on the French, Sardiniens, European and Hispanic Americans brought very similar results (Dina et al. 2007, Scuteri et al. 2007). The way by which the FTO product affects the energy balance is still unknown and its possible role in weight loss and its maintenance has not been studied so far.

\section{Monogenic and polygenic obesities}

Recently, several genes were identified whose mutations result in rare monogenic forms of human obesity (Farooqi and O'Rahilly 2006). Genes for leptin $(L E P)$, leptin receptor $(L E P R)$, pro-opiomelanocortin $(P O M C)$, melanocortin 4 receptor $(M C 4 R)$, melanocortin 3 receptor $(M C 3 R)$, prohormone convertase subtilisin/kexin type 1 (PCSK1), neurotrophic tyrosine kinase receptor type 2 (NTRK2), G protein-coupled 


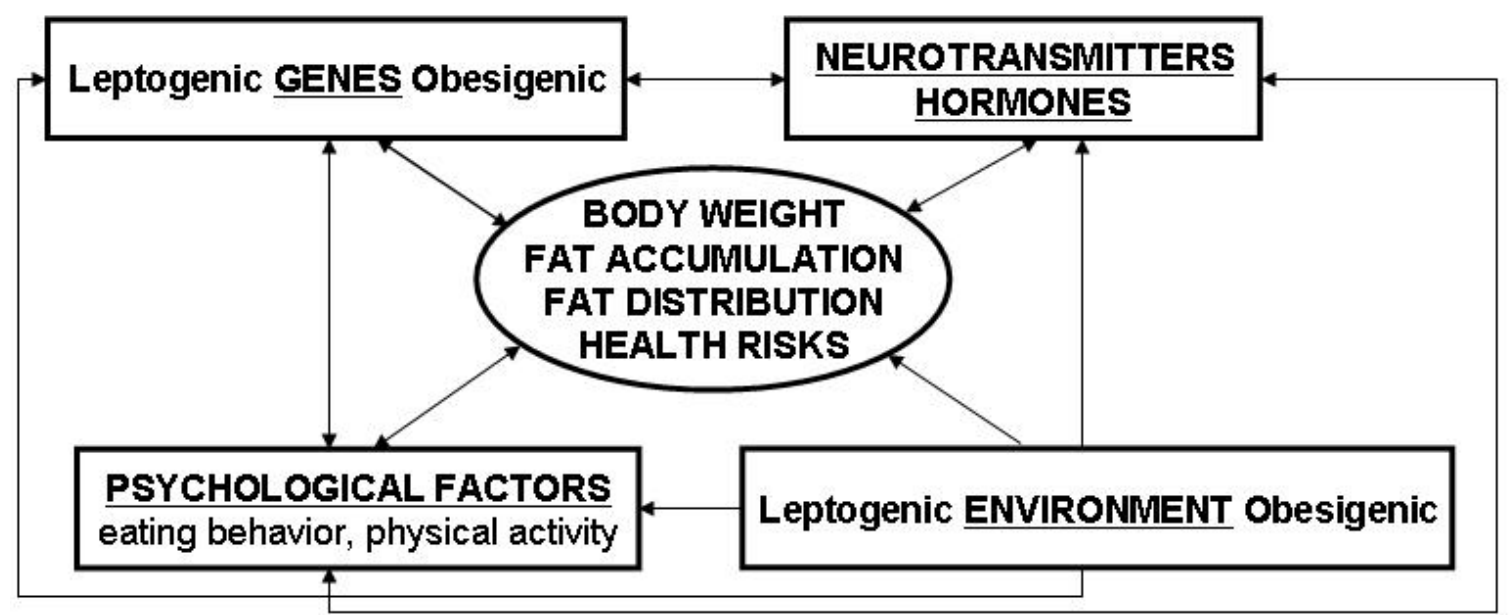

Fig. 1. Interactions between biological (genes, hormones and neurotransmitters), psychobehavioral and environmental factors affect body fat accumulation and fat distribution as well as obesity related health risks.

receptor 24 (GPR24), corticotropin releasing hormone receptor (CRHR2), corticotropin releasing hormone receptor (CRHR1) and the single-minded homolog 1 (SIMI) are among these genes (Rankinen et al. 2006, http://obesitygene.pbrc.edu). Nevertheless, mutations of these genes, with the exception of $M C 4 R$, belong to rather rare causes of human obesity (Farooqi and O'Rahilly 2006). MC4R mutations are found in $4-5 \%$ of severely obese subjects with early-onset obesity (Farooqi et al. 2003).

The heredity of common obesity is usually due to an interaction of multiple candidate genes found at different locations on the gene map and is therefore polygenic in nature. Candidate obesity genes either predispose to obesity (obesogenic genes) or promote leanness (leptogenic genes). Genes either interact with each other (gene-gene interactions) or with various environmental factors (gene-environment interactions). Interactions between biological (genes, hormones and neurotransmitters etc.), psychobehavioral and environmental factors influence body fat accumulation and fat distribution as well as obesity related health risks (Fig. 1). Such interactions result in a wide range of body weight phenotypes from morbid obesity to asthenic body habitus. In view of this polygenic character of obesity, the exact involvement of heredity and various candidate genes in obesity development is uneasy to quantify.

Association and linkage studies indicate links between candidate obesity genes and body weight, body mass index (BMI), body fat, fat distribution, energy expenditure, fuel oxidation and several other phenotypic characteristics of obesity including obesity related health risks (Rankinen et al. 2006).

\section{Genetic factors affecting body weight loss}

With the development of molecular genetics, research currently focuses on the role of genetic factors in body weight loss and maintenance. Studies carried out in monozygotic twins analyzed the interaction of genetic factors with weight loss programmes. Several studies emphasized the familial aggregation of ability to lose weight. The role of parental obesity in this respect was frequently demonstrated. Other studies dealt with the effects of polymorphism of candidate obesity genes on body weight loss and weight loss maintenance (MorenoAliaga et al. 2005). Weight loss maintenance is mainly influenced by psychobehavioral factors and even those factors are frequently genetically determined. Finally, recent studies have analyzed the impact of a weight loss intervention (characterized by energy and nutrient intake, type of physical activity) on the expression of candidate obesity genes (Viguerie et al. 2005a). Differences in expression of obesogenic and leptogenic genes with the type of dieting and physical activities may influence the efficacy of weight loss programmes.

\section{Studies on weight loss in monozygotic twins}

Studies that compared monozygotic and dizygotic twins found strong evidence for the influence of heredity on body weight. A study carried out on monozygotic twins revealed that genetic factors are very much involved in the determination of BMI (Stunkard et al. 1990). High correlation of BMI was shown in monozygotic in comparison to dizygotic twins regardless of whether or not they shared the same environment following their birth. It is well known from clinical experience that some obese subjects can achieve higher 
weight loss in response to the same negative energy balance than others. The role of genetic factors in different capabilities to lose weight was identified in studies conducted in monozygotic twins, i.e. individuals who possess identical genes (Bouchard et al. 1994, Hainer et al. 2000a). A study of Bouchard et al. (1994) described weight loss of slightly overweight identical twins in response to a negative energy balance induced by enhanced physical activity. Weight loss was similar in pairs of identical twins but differed significantly between pairs. A Czech study revealed a great similarity in weight and fat mass losses within the pairs of obese monozygotic twins in response to a one-month weight reduction programme which included a very low energy diet $\left(\right.$ Redita $^{\mathrm{R}}$ ) and a supervised aerobic exercise (Hainer et al. 2000a). Although body weight reduction showed wide interindividual variation, ranging between 5.9 to $12.4 \mathrm{~kg}$, reduction was similar in the pairs of monozygotic twins. The resemblance of the fat mass loss was 17 times higher within pairs than between pairs. Further analysis of this data demonstrated a high intra-pair correlation $(0.77)$ for metabolic efficiency (Hainer et al. 2001).

The important role of genetic factors in the control of eating behavior was shown in a Swedish study of young male twins which included 326 dizygotic and 456 monozygotic pairs of twins (Tholin et al. 2005). The within-pair correlations of the three scales (cognitive restraint, hunger and disinhibition) of the revised 21-item version of the Three Factor Eating Questionnaire (=Eating Inventory) were more than twice as high in the monozygotic twins as in the dizygotic twins. Further, cognitive restraint was significantly correlated with BMI (Tholin et al. 2005).

Family background of obesity, ability to oxidize fat and weight loss

In our previous study (Hainer et al. 2000b), a high fasting respiratory quotient (RQ) was observed during the very low calorie diet (VLCD) treatment in obese patients who regained weight at a 2-year follow-up ("weight regainers") and in those who exhibited repeated cycles of weight loss with a subsequent weight regain ("weight cyclers"). On the other hand, obese patients who succeeded in retaining the weight loss initially achieved by the VLCD at the 2-year follow-up ("weight losers") and those who did not exhibit weight fluctuations ("weight non-cyclers") were characterized by a significantly lower fasting RQ. A high fasting RQ during the VLCD treatment, which reflects low fat oxidation, should be therefore considered as a predictor of body weight gain. Obese subjects who reported parental obesity demonstrated significantly higher fasting RQ than those who reported normal weight in both parents. Differences in RQ in connection with parental obesity remained statistically significant even after adjustment for confounders such as BMI, weight, fat mass, waist circumference, gender, age, average macronutrient intake during the week preceding calorimetry and serum levels of insulin and C-peptide. Obese subjects with both parents obese were found 3.3 times more frequently ( 42.8 $\%$ vs. $12.9 \%$ ) in the upper quintile of RQ cohort (low fat oxidizers) than in the lower quintile of RQ cohort (high fat oxidizers). In contrast, obese individuals with normal weight parents were revealed much more frequently in the lower quintile of RQ than in the upper quintile of RQ (38.7\% vs. $7.1 \%)$.

It is evident that the ability to oxidize fat, which affects the outcome of weight reduction programme, is greatly influenced by family background of obesity. Not only fasting RQ but also 24-hr RQ is controlled by familial factors. Toubro et al. (1998) revealed that familial membership explained $27 \%$ of the variation in 24-hr RQ between individuals. On the other hand, a high intake of dietary fat was significantly associated with weight gain only in women with parental history of obesity (Heitmann et al. 1995). This susceptibility to weight gain after a high consumption of fat in individuals with parental history of obesity might be due to the familial determination of the ability to oxidize fat both during fasting and after fat load. Recently, several genes associated with the low lipid oxidation genotype have been described (Table 1, Rankinen et al. 2006, Bouchard 2007).

\section{Weight loss in monogenic forms of obesity}

Since the monogenic forms of obesity are rather scarce, only few reports on efficacy of the therapy are available. It could be expected that correctly targeted therapy of obesity caused by gene mutations should be highly succesful. Obesity due to leptin gene mutation is the only type of obesity caused by single gene mutation which has been effectively treated to date. A daily subcutaneous administration of recombinant leptin both in adults and children leads to weight normalization (Licinio et al. 2004, O'Rahilly et al. 2003). In view of the known role of genes in the pathogenesis of obesity, some physicians may adopt a nihilist attitude to the treatment of this disorder. Nevertheless, such an approach is 
Table 2. Obesity candidate genes that influence weight loss in weight management programmes.

\begin{tabular}{ll}
\hline Gene & Polymorphism \\
\hline LEP & C-2549A (5' region) \\
LEPR & Ser343Ser (T/C); Lys656Asn \\
HTR2C & C-759T \\
NMB & Pro73Thr \\
PLIN & G11482A \\
PPARG2 & Pro12Ala \\
ADRB2 & Arg16Gly \\
ADRB3 & Trp64Arg \\
UCP1 & A-3826G \\
UCP2 & G-866A \\
UCP3 & C-55T \\
IL6 & G-174C \\
IRS & Gly972Arg \\
CYP1 & (TTTA)11 \\
COMT & Val158Met \\
PNMT & G-148A \\
GNB3 subunit & C825T \\
\hline
\end{tabular}

unjustified as also shown by the last report on body weight, body fat mass and insulin susceptibility normalization following an 11-month comprehensive weight loss intervention in three children with $\mathrm{R} 236 \mathrm{G}$ mutation in $P O M C$. It has been shown that weight reduction interventions may have also an impact on body weight, body fat mass and further obesity features in cases of genetic disorders as in the case of $P O M C$ (Santoro et al. 2006). The most common monogenic form of human obesity is that caused by mutations in the $M C 4 R$ which is associated with intensive feeling of hunger and hyperphagia in childhood which decreases with aging (Vaisse et al. 1998). The first preliminary study evaluated the response to a weight reduction programme in four $M C 4 R$ carriers and compared it to non-carriers (Hainerová et al. 2007). No differences in weight loss between carriers and non-carriers were observed. This finding supports an assumption that mutations in $M C 4 R$ do not negatively impact the ability to lose body weight (Hainerová et al. 2007). This observation is in agreement with an experimental study of Butler and Cone (2003) who described hyperphagia in $M C 4 R$ deficient mice fed with a high-fat diet, in which no hyperphagia was observed when a low-fat diet was introduced. This study on gene-environment interaction supports the role of low-fat diet in the ability to control weight even in genetically determined obesities. A recent study conducted in 184 obese children showed a clear gene-diet interaction between the MC3R Thr6Lys and Val81Ile variants and a weight loss programme for the ability to lose weight (Santoro et al. 2007).

\section{Polymorphisms of obesity candidate genes and weight loss}

Polymorphisms of several genes have been studied with regard to weight loss and weight loss maintenance in common obesity, which is characterized by polygenic heredity (Table 2 ).

Beta 3 adrenoreceptor ( $A D R B 3)$ plays an important role in adipocyte metabolism as a regulator of catecholamine-induced lipolysis. Among frequent polymorphisms of the ADRB3 gene is the Trp64Arg variant. There have been studies which have focused on the effect of the Trp64Arg polymorphism of the ADRB3 gene on long-term weight loss regimens. It has been shown that homozygotes for the Arg64 allele are less successful in reducing weight than Trp64 carriers (Yoshida et al 1995). Other Japanese studies (Sakane et al. 1997, Shiwaku et al. 2003) also confirmed that women with the Arg64 allele lose weight more slowly when enrolled in a weight loss programme. Another study reported Arg64 allele carriers to achieve almost 50 $\%$ lower weight loss compared to wild-type subjects when given the antiobesity drug mazindol (Shimizu and Mori 2004). On the contrary, results of many studies found no differences in weight loss in persons with various polymorphisms of the $A D R B 3$ gene (Fumeron et al. 1996, Tchernof et al. 2000, Kim et al. 2003, Rawson et al. 2002). No differences in body composition and energy expenditure was found between the Arg64 carriers and non-carriers following weight loss (Rawson et al. 2002). These discordances could be due to a lack of homogeneity of the study groups (obese versus nonobese subjects, diabetics versus nondiabetics) or to ethnic differences. However, a study in Chinese children aged 811 years reported a significant body weight decrease in Arg64 carriers (Xinli et al. 2001). Another study dealt with the effect of the Trp64Arg polymorphism on body fat distribution during weight reduction (Nakamura et al. 2000). Following a three-month weight reduction regimen, Arg64 carriers compared to Arg64 non-carriers showed a lower ratio of visceral to subcutaneous fat, which was particularly true of postmenopausal women. Further studies reported visceral fat reduction to be lower 
in the Arg allele carriers compared to non-carriers after intervention (Tchernof et al 2000, Kim et al. 2003).

Kawaguchi et al. (2006) investigated common polymorphisms of beta 2 adrenoreceptor (ADRB2) and $A D R B 3$ in obese subjects followed over 5 years. Subjects with weight gain had higher frequencies of the Gly16 allele (polymorphism Arg16Gly) of ADRB2 and the Arg64 allele of ADRB3. Carriers of Gly16 and Arg64 alleles had significantly greater total fat-mass and waistto-hip ratio both at entry and over a 5 -year period compared to the non-carriers. The role of ADRB2 in weight loss maintenance over a 2-year follow-up period was also demonstrated in the study by Masuo et al. (2005). Regaining body weight was associated with high plasma norepinephrine levels that were mediated through polymorphisms in the ADRB2. The Gly16 allele predicted those subjects who would regain weight after the initial weight loss. Individuals with weight regain had a significantly higher frequency of the Gly16 allele for the $A D R B 2$ polymorphism compared to subjects who exhibited 24-month maintenance of weight loss. Carriers of the Gly16 allele also had significantly higher plasma levels of leptin and norepinephrine, and an increased body fat mass and waist-to-hip ratio both at entry and throughout the study.

Benecke et al. (2000) described synergism between $A D R B 3$ polymorphism (Trp64Arg) and insulin receptor substrate (IRS-1) gene polymorphism (Gly972Arg) in weight loss control. The coincidence of these two polymorphisms was linked to lower weight loss and higher incidence of type 2 diabetes in obese women following a 13-week weight loss intervention. The question remains unanswered whether the presence of these polymorphisms is one of the major causes of lower weight loss as observed in most diabetics on a weight reduction regimen.

Recently, a large genetic association study showed evidence for association of the SNP rs7566605 which lies approximately $10 \mathrm{~kb}$ upstream of the insulininduced gene 2 (INSIG2) with obesity in several cohorts (Herbert et al. 2006). Reinehr et al. (2007) confirmed that children homozygous for the $\mathrm{C}$-allele of this polymorphism lose less weight after a 1 year lifestyle intervention than children with the GG- or GCgenotypes. This finding supports the role of this polymorphism in weight regulation.

Peroxisome proliferator-activated receptor gamma 2 (PPARG2) is an intracellular transcription factor that plays a role in adipogenesis and glucose and lipid homeostasis. A metaanalysis of Pro12Ala polymorphism of the PPARG2 gene showed positive correlation with BMI. Higher BMI scores were also found in Ala12 carriers compared to Ala12 non-carriers in a 10-year follow-up study and a 3-year follow-up study (Ek et al. 1999, Lindi et al. 2001). Intervention studies were carried out to elucidate the relationship between the PPARG2 genotype and weight loss. Homozygotes for the Ala12 allele were more successful in reducing body weight than patients with other genotypes (Lindi et al. 2001). On the other hand, later study showed significantly different frequency distribution for the PPARG2 genotypes between the successful (weight maintenance after weight loss $<10 \%$ regain) and the unsuccessful group (weight maintenance after weight loss $>10 \%$ regain) (Vogels et al. 2005). The study of Kim et al. (2003) suggests that the Ala12 allele carriership is associated with increased subcutaneous and visceral fat areas in overweight Korean female subjects, but does not significantly affect one-month weight loss programmes. No associations between Pro12Ala PPARG2 polymorphism and body mass changes were observed in obese patients with long-lasting type 2 diabetes (Stefanski et al. 2006). A study conducted in 70 postmenopausal overweight and obese women demonstrated that six months of hypocaloric diet induced the same weight loss in both women homozygous for the Pro12 allele and those carrying the Ala12 allele (Nicklas et al. 2001). However, the weight regain during follow-up was significantly greater in women with the Ala12 allele than women homozygous for the Pro12 allele. It should be evaluated whether such a susceptibility to weight regain in the Ala12 carriers might be due to decreased fat oxidation in response to a hypocaloric diet (Nicklas et al. 2001). On the other hand, our pilot study of 108 obese patients did not reveal any significant difference in weight loss between carriers and non-carriers of the Ala12 allele over the 4-year period of follow-up (Aldhoon et al. 2004).

Uncoupling proteins (UCPs) are a family of transmembrane proteins located on the inner mitochondrial membrane. Their function is to uncouple the ATP formation from mitochondrial respiration which results in increased heat formation and higher energy expenditure. Uncoupling protein 1 (UCP1), whose main expression site is brown adipose tissue plays an important role in thermogenesis. Uncoupling protein 2 (UCP2) is similar in structure to uncoupling protein 3 (UCP3), but unlike UCP3 which is found exclusively in skeletal 
muscle, it is present in several tissues. Uncoupling proteins play an important role in energy metabolism since they act as transmembrane transporters across the inner mitochondrial membrane in cells. Several studies demonstrated correlations between UCP gene polymorphisms and resting energy expenditure, physical activity efficacy, substrate oxidation, energy metabolism, BMI, obesity and type 2 diabetes. A study of the UCPI gene revealed that the A-3826G polymorphism is linked to lower weight loss in response to a $25 \%$ reduction of energy intake (Fumeron et al. 1996). Shin et al. (2005) described one haplotype ht3[GAG] of UCPl and found an association with an accelerated reduction of waist-tohip ratio and fat mass in response to one-month VLCD treatment among Korean females.

Harper et al. (2002) reported higher UCP3 mRNA expression in persons responsive to dietary intervention compared to those who were resistant to dietary measures. A recent study investigated the effect of ten polymorhisms (including four of $U C P 2$ and six of $U C P 3)$ on obesity phenotypes and weight changes after VLCD. Statistical analysis revealed significant associations between one of the major haplotypes of UCP2-3 gene cluster, ht1 (GGCdelCGTACC), and UCP2 promoter variant G-866A with VLCD-induced fat reduction. Authors suggested that UCP2-3 polymorphisms represent important genetic predictors of the VLCD-induced reduction of body fat mass (Yoon et al. 2007).

Leptin $(L E P)$. Patients with common obesities often have high leptin levels that may indicate leptin resistance. Leptin administration in these obese patients usually does not promote weight loss. However, baseline leptin levels were shown as suitable weight loss predictors in obesity. High pretreatment baseline leptin levels as markers of leptin resistance were associated with decreased weight loss in response to a short term weight reducing regimen lasting 24 weeks (Verdich et al. 2001) as well as to a 2-year cognitive behavioral intervention (Naslund et al. 2000). Leptin gene polymorphism in the promoter region $5^{\prime}$ is linked to lower weight loss in response to low-energy diet (Mammes et al. 1998).

Two reports on the effect of the leptin receptor (LEPR) gene polymorphism on weight loss in obese persons have been published. Female carriers of the $\mathrm{C}$ allele of the leptin receptor gene silent polymorphism Ser343Ser $(\mathrm{T} / \mathrm{C})$ were shown to be more successful in a dietary weight loss intervention (Mammes et al. 2001).
De Luis Roman et al. (2006) investigated the influence of Lys656Asn polymorphism in the LEPR on leptin response and weight loss secondary to a lifestyle modification in obese patients. Subjects with the Asn656 allele of $L E P R$ exhibited similar weight loss in response to weight management as Lys656 homozygotes. In contrast to the wild type group, no decrease of leptin level after weight loss was demonstrated in the carriers of the Asn656 allele.

5-hydroxytryptamine (serotonin) receptor $2 \mathrm{C}$ (HTR2C). Serotonin is involved in food intake regulation in the central nervous system (CNS) by inducing satiety. The CNS serotonin receptors mediate the effects of serotonin on food intake control. The promoter polymorphism C-759T of the HTR2C is linked to lower weight loss in weight reduction intervention for heterozygotes compared to both CC and TT homozygotes (Pooley et al. 2004). A higher frequency of the serine allele (polymorphism Cys23Ser) of the serotonin receptor gene was shown to be linked to weight loss in adolescent females and might also be involved in the development of anorexia nervosa (Westberg et al. 2002).

Subclass 19 cytochrome $\mathbf{P 4 5 0}$ aromatase
$(C Y P 19) \quad$ and
catechol-ortho-methyltransferase (COMT). The concomitance of the defined polymorphisms in the genes CYP19 (repeat polymorphism (TTTA) ${ }_{11}$ ) and COMT (Val158Val) leads to a significantly larger reduction in BMI and body fat in response to a one-year regular exercise programme in overweight and obese postmenopausal women (Tworoger et al. 2004). It is suggested that genetic polymorphisms in CYP19 and COMT genes may be important for body fat regulation and possibly modify the effect of exercise on fat mass loss in postmenopausal women.

Perilipins $(P L I N)$ are a family of proteins that coat the intracellular lipid droplets and they are essential in the regulation of triglyceride depositon and mobilization (Mottagui-Tabar et al. 2003). Significant positive relationship between perilipin mRNA levels and percent body fat as well as between the perilipin protein and BMI have been observed (Qi et al. 2004). In addition, multivariate analysis demonstrated that two of the single nucleotide polymorphisms (SNPs) (A13041G and A14995T) were significantly associated with percentage body fat and waist circumference in women. It seems that women are more sensitive to the genetic effects of perilipin than men (Qi et al. 2004). Polymorphism of the perilipin gene (G11482A) may also predict the outcome of body weight reduction strategies based on low-energy 
diets as obese patients carrying the $11482 \mathrm{~A}$ allele were resistant to one-year weight management programme with a low-energy diet (Corella et al. 2005).

\section{Genes affecting response to drug treatment of obesity}

As mentioned above, the carriers of Trp64Arg polymorphism of $A D R B 3$ exhibited lower weight loss in response to mazindol treatment (Shimizu and Mori 2004). Phenylethanolamine N-methyltransferase (PNMT) is an enzyme which plays a major role in catecholamine metabolism and catalyzes the conversion of norepinephrine to epinephrine. The AA homozygotes (G148A polymorphism) showed higher weight loss in a 3month therapy with the antiobesity drug sibutramine (Peters et al. 2003). Serotonin transporter which is involved in mood and eating disturbances, is encoded by the gene solute carrier family 6 (neurotransmitter transporter, serotonin), member 4 (SLC6A4). The promoter for SLC6A4 shows functional insertion/deletion alleles resulting into long (L) and short (S) alleles. Individuals who are carriers for the short version are at risk of adolescent obesity (Sookoian et al. 2007) and higher levels of anxiety whereas the LS/SS genotype was associated with enhanced weight loss after treatment with sibutramine (Vazquez Roque et al. 2007).

Guanine nucleotide-binding protein (Gprotein), beta-3 subunit (GNB3) C825T polymorphism influenced weight loss differently in placebo controls and study subjects given a serotonin-noradrenaline ereuptake inhibitor sibutramine (Hauner et al. 2003). The placebo controls with the TT/TC genotypes showed higher weight loss compared to those with the $\mathrm{CC}$ genotype. The individuals with the $\mathrm{CC}$ genotype exhibited higher weight loss in response to sibutramine administration compared to those with the TT/TC genotypes. Studies on druginduced weight loss provide additional evidence that genotyping could be of relevance in predicting efficacy of antiobesity drugs for obesity treatment.

\section{Genes affecting response to bariatric surgery}

Weight loss at the 6-month follow-up after laparoscopic gastric banding was influenced by polymorphisms in interleukin 6 (IL6) and UCP2 genes (Sesti et al. 2005). Carriers of G-174G IL6 genotype lost more weight than $\mathrm{G}-174 \mathrm{C}$ or $\mathrm{C}-174 \mathrm{C}$ genotype whereas carriers of A-866A UCP2 genotype lost more weight in comparison with carriers of G-866G and G-866A genotypes. 304 severely obese patients were followed for at least 3 years after gastric banding and their weight loss was not predicted by any of the $\mathbf{G}$ protein gene polymorphisms (Potoczna et al. 2004).

The most comprehensive studies on genenutrient interaction are represented by the NUGENOB project (Nutrient-Gene Interactions in Human Obesity: Implications for Dietary Guidelines). A NUGENOB study conducted in eight clinical centers across Europe investigated the role of gene-diet interaction on weight loss (Sorensen et al. 2006). In this study 26 obesity candidate genes and 42 SNPs were followed in relation to weight loss in 648 obese adults treated by a hypoenergetic low-fat or high-fat diet for 10 weeks. Authors did not succeed in demonstrating a major influence of any of these genetic polymorphisms on the clinical outcome of the dietary intervention, although the most frequent variants of genes involved in energy balance regulation were studied. However, the study suggests that SNPs in the prohormone convertase subtilisin/kexin type $\mathbf{1}(P C S K 1)$, WW domain containing adaptor with coiled-coil $(W A C)$, 11betahydroxysteroid dehydrogenase type 1 (HSD11B1), and tumor necrosis factor alfa (TNFA) genes and possibly haplotypes of the glutamic acid decarboxylase 2 (GAD2) and ectonucleotide pyrophosphatase/ phosphodiesterase 1 (ENPP1) genes may modulate dietinduced weight changes (Sorensen et al. 2006). It is possible that more severe energy restriction and more prolonged weight management program are required to reveal the role played by gene-diet interaction in weight loss programs.

Another NUGENOB study investigated an expression of genes in subcutaneous adipose tissue in two groups of 25 obese subjects followed over a 10-week administration of low-fat or high-fat hypocaloric diets (Viguerie et al. 2005b). The expression of ten of 38 investigated genes were influenced by energy intake. Energy deficit and/or weight loss rather than the ratio of fat to carbohydrate in a hypocaloric diet modified the expression of genes in the human adipose tissue. Levels of PPARG co-activator 1alpha mRNA were increased, whereas the expressions of the genes encoding leptin, osteonectin, phosphodiesterase 3B, hormone-sensitive lipase, receptor $\mathrm{A}$ for natriuretic peptide, fatty acid translocase, lipoprotein lipase, UCP2 and PPARG were decreased.

Ruaño et al. (2006) studied weight loss in 86 normal weight and overweight healthy adults who kept a low carbohydrate ( $\mathrm{CHO} 10 \%$ of total energy intake) ketogenic diet for 4-12 weeks. Mean weight loss in 
response to dietary intervention was $6.4 \mathrm{~kg}$. SNPs in the gastric lipase $(L I P F)$, hepatic glycogen synthase (GYS2), cholesteryl ester transfer protein (CETP) and galanin $(G A L)$ genes were significantly associated with weight loss. One should be aware of the limitations of the study concerning further clinical implications. The studied cohort included normal weight and overweight subjects and not obese patients and a very low carbohydrate diet which should not be recommended for the treatment of obesity was employed in the study protocol.

\section{Eating behavior and weight loss}

Weight loss maintenance largely depends on psychobehavioral factors such as the type of eating behavior. In a recent study weight loss in response to a one-year weight loss programme including treatment with the antiobesity drug sibutramine was significantly associated with a decrease in disinhibition scores (Hainer et al. 2005) as assessed by the Eating Inventory (Stunkard and Messick 1985). Disinhibition score is a characteristic of eating behaviour of a person prone to non-compliance with a weight loss regimen and to overeating in response to stress, job and family related problems, increased alcohol intake, anxiety and depression. Disinhibition scores show a strong hereditary link (heredity rate of $40 \%$ ) and the gene on chromosome 3, which is most linked to disinhibition, also codes for PPARG (Steinle et al. 2002). Experimental studies conducted in rats revealed the role of neuromedin beta $(N M B)$, a member of the family of bombesin-like peptides, in the control of food intake (Rushing et al. 1996, Ladenheim et al. 1997). Recently, a gene on chromosome 15 encoding $N M B$ was characterized as a potential candidate gene determining disinhibition and hunger factors of the Eating Inventory (Bouchard et al. 2004). NMB gene polymorphism (Pro73Thr) was linked not only to higher disinhibition and more hunger but also to greater body fat accumulation in their 6-year follow-up study (Bouchard et al. 2004). A cohort of 332 adult subjects from the Québec Family Study with a wide range of adiposity was followed over a period of 6-10 years and associations of weight changes with 15 polymorphisms in 10 candidate genes were tested. Changes in fat mass over this period were predicted by the polymorphisms of several obesity candidate genes including $N M B$ and explained $8.5 \%$ of the fat mass variance. Other genes which retained in prediction model for changes in fat mass were leptin, Gprotein, $A D R B 3$ and $P P A R G$. The effects of genes on body weight change was stronger in younger compared to older individuals (Bouchard L et al. 2007). Our study revealed higher total energy intake, higher lipid and protein intake and higher hunger score in overweight and obese men homozygous for the Pro73 allele compared to both other genotypes (Spálová et al. 2008). Nevertheless, the previous study of Oeffner et al. (2000) failed to show any relation of the Pro73Thr $N M B$ polymorphism to body weight, while a significant association between G401A polymorphism and body weight was revealed. This study did not follow the association of the $N M B$ polymorphisms with eating behavior characteristics. A study performed in children found that genetic interaction involving $A D R B 3$ and PPARG variants influences eating behavior (Cecil et al. 2007). Poor postprandial compensation index was associated with the PPARG T1431 allele. Significant role of the $A D R B 3$ Trp64Arg variant in modulating compensation was also demostrated. The Arg64 allela was associated with a better compensation. The study of De Krom et al. (2007) tested several single nucleotide polymorphisms in the candidate genes and their effect on eating patterns. They found that obese carriers of common allelic variations in the $L E P$ or $L E P R$ had an increased risk to display extreme snacking behavior and obese carriers of the common allelic variation in cholecystokinin had an increased risk of eating increased meal size.

This review summarizes the actual findings on the genetic background of obesity focusing especially on the role of hereditary factors in weight change. It has been demonstrated that polymorphisms of several obesity candidate genes affect weight loss and maintenance in response to weight reducing programmes. Nevertheless, some results of the studies presented are not completely consistent. These discordances could be due to a lack of homogeneity of the study groups (ethnic, gender, age differences, different levels of adiposity, absence or presence of concomitant disorders etc.). The statistic meta-analysis of already published results could bring resolution of this topic.

It should be expected that improving our knowledge about genetic determinants of the outcome of weight management could assist in development of more effective and individually tailored therapeutic strategies.

\section{Abbreviations}

ACE, angiotensin I converting enzyme; ADIPOQ, adiponectin, $\mathrm{C} 1 \mathrm{Q}$ and collagen domain containing; ADRB2, beta-2 adrenoreceptor; ADRB3, beta-3 
adrenoreceptor; BMI, body mass index; CETP, cholesteryl ester transfer protein; CNS, central nervous system; COMT, catechol-ortho-methyltransferase; CRHR1, corticotropin releasing hormone receptor 1; CRHR2, corticotropin releasing hormone receptor 2; CYP19, subclass 19 cytochrome P450 aromatase; DRD2, dopamine receptor D2; ENPP1, ectonucleotide pyrophosphatase/phosphodiesterase 1; FTO, fat mass and obesity associated gene; GAD2, glutamate decarboxylase 2; GAL, galanin; GNB3, guanine nucleotide-binding protein (G-protein), beta-3 subunit; GPR24, G proteincoupled receptor 24; GYS2, glycogen synthase 2; HSD11B1, 11beta-hydroxysteroid dehydrogenase type 1; HTR2C, 5-hydroxytryptamine (serotonin) receptor 2C; IL6, interleukin 6; INS, insulin; INSIG2, insulin-induced gene 2; IRS1, insulin receptor substrate 1; LDLR, low density lipoprotein receptor; LEP, leptin; LEPR, leptin receptor; LIPE, lipase, hormone-sensitive; LIPF, gastric lipase; MC3R, melanocortin 3 receptor; MC4R, melanocortin 4 receptor; NMB, neuromedin beta; NR3C1, nuclear receptor subfamily 3, group C, member 1 (glucocorticoid receptor); NTRK2, neurotrophic tyrosine kinase receptor type 2; PCSK1, prohormone convertase subtilisin/kexin type 1; PLIN, perilipin; POMC, pro-opiomelanocortin; PPARG, peroxisome proliferator-activated receptor gamma; RQ, respiratory quotient; SIM1, single-minded homolog 1; SLC6A4, solute carrier family 6 (neurotransmitter transporter, serotonin), member 4; SNP, single nucleotide polymorphism; TNFA, tumor necrosis factor alfa; UCP1, uncoupling protein 1; UCP2, uncoupling protein 2; UCP3, uncoupling protein 3; VDR, vitamin D $(1,25-$ dihydroxyvitamin D3) receptor; VLCD, very low calorie diet; WAC, WW domain-containing adapter with a coiled-coil region.

\section{Conflict of Interest}

There is no conflict of interest.

\section{Acknowledgements}

This study was supported by grant IGA NR 7800-4 provided by the Czech Ministry of Health and by the research project of MSM No. 0021620814.

\section{References}

ALDHOON B, HAINER V, BENDLOVÁ B, KUNEŠOVÁ M, PAŘÍZKOVÁ J, KABRNOVÁ K, BRAUNEROVÁ R, WAGENKNECHT M, ŠRÁMKOVÁ D, HLAVATÝ P: PPAR gamma polymorphism in obesity: Weight-loss maintenance, psychobehavioral indexes and energy intake during 4-year folow-up. Int J Obes Relat Metab Disord 28 (Suppl 1): S105, 2004.

BELL CG, WALLEY AJ, FROGUEL P: The genetics of human obesity. Nat Rev Genet 6: 221-234, 2005.

BENECKE H, TOPAK H, VON ZUR MUHLEN A, SCHUPPERT F: A study on the genetics of obesity: influence of polymorphisms of the beta-3-adrenergic receptor and insulin receptor substrate 1 in relation to weight loss, waist to hip ratio and frequencies of common cardiovascular risk factors. Exp Clin Endocrinol Diabetes 108: 86-92, 2000.

BOUCHARD C: The biological predisposition to obesity: beyond the thrifty genotype scenario. Int $J$ Obes 31: 13371339, 2007.

BOUCHARD C, TREMBLAY A, DESPRES J-P, THERIAULT G, NADEAU A, LUPIEN PJ, MOORJANI S, PRUDHOMME D, FOURNIER G: The response to exercise with constant energy intake in identical twins. Obes Res 2: 400-410, 1994.

BOUCHARD L, DRAPEAU V, PROVENCHER V, LEMIEUX S, CHAGNON Y, RICE T, RAO DC, VOHL MC, TREMBLAY A, BOUCHARD C, PÉRUSSE L: Neuromedin beta: a strong candidate gene linking eating behaviors and susceptibility to obesity. Am J Clin Nutr 80: 1478-1486, 2004.

BOUCHARD L, TREMBLAY A, BOUCHARD C, PÉRUSSE L: Contribution of several candidate polymorphisms in the determination of adiposity changes: results from the Québec Family Study. Int J Obes 31: 891-899, 2007.

BUTLER AA, CONE RD: Knockout studies defining different roles for melanocortin receptors in energy homeostasis. Ann NY Acad Sci 994: 240-245, 2003.

CECIL JE, PALMER CNA, FISCHER B, WATT P, WALLIS D, MURRIE I, HETHERINGTON MM: Variants of the peroxisome proliferator-activated receptor beta and B-adrenergic receptor genes are associated with measures of compensatory eating behaviors in young children. Am J Clin Nutr 86: 167-173, 2007. 
COMUZZIE AG, ALLISON DB: The search for human obesity genes. Science 280: 1374-1377, 1998.

CORELLA D, QI L, SORLÍ JV, GODOY D, PORTOLÉS O, COLTELL O, GREENBERG AS, ORDOVAS JM: Obese subjects carrying the $11482 \mathrm{G}>\mathrm{A}$ polymorphism at the perilipin locus are resistant to weight loss after dietary energy restriction. J Clin Endocrinol Metab 90: 5121-5126, 2005.

DE KROM M, VAN DER SCHOUW YT, HENDRIKS J, OPHOFF RA, VAN GILS CH, STOLK RP, GROBBEE DE, ADAN R: Common genetic variations in CCK, leptin, and leptin receptor genes are associated with specific human eating patterns. Diabetes 56: 276-280, 2007.

DE LUIS ROMAN D, De LA FUENTE RA, SAGRADO MG, IZAOLA O, VICENTE RC: Leptin receptor Lys656Asn polymorphism is associated with decreased leptin response and weight loss secondary to a lifestyle modification in obese patients. Arch Med Res 37: 854-859, 2006.

DINA C, MEYRE D, GALLINA S, DURAND E, KORNER A, JACOBSON P, CARLSSON LM, KIESS W, VATIN V, LECOEUR C, DELPLANQUE J, VAILLANT E, PATTOU F, RUIZ J, WEILL J, LEVY-MARCHAL C, HORBER F, POTOCZNA N, HERCBERG S, LE STUNFF C, BOUGNERES P, KOVACS P, MARRE M, BALKAU B, CAUCHI S, CHEVRE JC, FROGUEL P: Variation in FTO contributes to childhood obesity and severe adult obesity. Nat Gene 39: 724-726, 2007.

EK J, URHAMMER SA, SORENSEN TI, ANDERSEN T, AUWERX J, PEDERSEN O: Homozygosity of the Pro12Ala variant of the peroxisome proliferation-activated receptor.gamma2 (PPAR-gamma2): divergent modulating effects on body mass index in obese Caucasian men. Diabetologia 42: 892-895, 1999.

FAROOQI S, O'RAHILLY S: Genetics of obesity in humans. Endocr Rev 27: 710-718, 2006.

FAROOQI IS, KEOGH JM, YEO GSH, LANK EJ, CHEETHAM T, O'RAHILLY S: Clinical spectrum of obesity and mutations in the melanocortin 4 receptor gene. $N$ Engl J Med 348: 1085-1095, 2003.

FRAYLING TM, TIMPSON NJ, WEEDON MN, ZEGGINI E, FREATHY RM, LINDGREN CM, PERRY JR, ELLIOTT KS, LANGO H, RAYNER NW, SHIELDS B, HARRIES LW, BARRETT JC, ELLARD S, GROVES CJ, KNIGHT B, PATCH AM, NESS AR, EBRAHIM S, LAWLOR DA, RING SM, BENSHLOMO Y, JARVELIN MR, SOVIO U, BENNETT AJ, MELZER D, FERRUCCI L, LOOS RJ, BARROSO I, WAREHAM NJ, KARPE F, OWEN KR, CARDON LR, WALKER M, HITMAN GA, PALMER CN, DONEY AS, MORRIS AD, SMITH GD, HATTERSLEY AT, MCCARTHY MI: A common variant in the FTO gene is associated with body mass index and predisposes to childhood and adult obesity. Science 316: 889-894, 2007.

FUMERON F, DURACK-BOWN I, BETOULLE D, CASSARD-DOULCIER AM, TUZET S, BOUILLAUD F, MELCHIOR JC, RICQUIER D, APFELBAUM M: Polymorphisms of uncoupling protein (UCP) and beta 3 adrenoreceptor genes in obese people submitted to a low calorie diet. Int J Obes Relat Metab Disord 20: 10511054, 1996.

HAINER V, STUNKARD AJ, KUNEŠOVÁ M, PAŘÍZKOVÁ J, ŠTICH V, ALLISON DB: Intrapair resemblance in very low calorie diet-induced weight loss in female obese identical twins. Int $J$ Obes Relat Metab Disord 24: 1051-1057, 2000a.

HAINER V, KUNEŠOVÁ M, PAŘÍZKOVÁ J, ŠTICH V, MIKULOVÁ R, SLABÁ S: Respiratory quotient in obesity: its association with an ability to retain weight loss and with parental obesity. Sborn Lek 101: 99-104, 2000b.

HAINER V, STUNKARD A, KUNEŠOVÁ M, PAŘÍZKOVÁ J, ŠTICH V, ALLISON DB: A twin study of weight loss and metabolic efficiency. Int J Obes 25: 533-537, 2001.

HAINER V, KUNEŠOVÁ M, BELLISLE F, HILL M, BRAUNEROVÁ R, WAGENKNECHT M: Psychobehavioral and nutritional predictors of weight loss in obese women treated with sibutramine. Int $J$ Obes Relat Metab Disord 29: 208-216, 2005.

HAINEROVÁ I, LARSEN LH, HOLST B, FINKOVÁ M, HAINER V, LEBL J, HANSEN T, PEDERSEN O: Melanocortin 4 receptor mutations in obese Czech children: studies of prevalence, phenotype development, weight reduction response and functional analysis. J Clin Endocrinol Metab 92: 3689-3696, 2007.

HARPER ME, DENT R, MONEMDJOU S, BEZAIRE V, VAN WYCK L, WELLS G, KAVASLAR GN, GAUTHIER A, TESSON F, MCPHERSON R: Decreased mitochondrial proton leak and reduced expression of uncoupling protein 3 in skeletal muscle of obese diet-resistant women. Diabetes 51: 2459-2466, 2002. 
HAUNER H, MEIER M, JOCKEL KH, FREY UH, SIFFERT W: Prediction of successful weight reduction under sibutramine therapy through genotyping of the G-protein beta3 subunit gene (GNB3) C825T polymorphism. Pharmacogenetics 13: 453-459, 2003.

HEITMANN BL, LISSNER L, SORENSEN TIA, BENGTSSON C: Dietary fat intake and weight gain in women genetically predisposed for obesity. Am J Clin Nutr 61: 1213-1217, 1995.

HERBERT A, GERRY NP, MCQUEEN MB, HEID IM, PFEUFER A, ILLIG T, WICHMANN HE, MEITINGER T, HUNTER D, HU FB, COLDITZ G, HINNEY A, HEBEBRAND J, KOBERWITZ K, ZHU X, COOPER R, ARDLIE K, LYON H, HIRSCHHORN JN, LAIRD NM, LENBURG ME, LANGE C, CHRISTMAN MF: A common genetic variant is associated with adult and childhood obesity. Science 312: 279-283, 2006.

KAWAGUCHI H, MASUO K, KATSUYA T, SUGIMOTO K, RAKUGI H, OGIHARA T, TUCK ML: Beta2- and beta3-adrenoceptor polymorphisms relate to subsequent weight gain and blood pressure elevation in obese normotensive individuals. Hypertens Res 29: 951-959, 2006.

KIM OY, LEE YA, RYU HJ, PARK HY, JANG Y, LEE JH: Effect of Trp64Arg mutation in the beta3-adrenoceptor gene on body fat distribution, glycemic control and lipids in response to hypocaloric diets in men with coronary artery disease. Nutr Res 23:1013-1025, 2003.

LADENHEIM EE, TAYLOR JE, COY DH, CARRIGAN TS, WOHN A, MORAN TH: Caudal hidbrain neuromedin B-preferring receptors participace in the control of food intake. Am J Physiol 272: R433-R437, 1997.

LICINIO J, CAGLAYAN S, OZATA M, YILDIZ BO, DE MIRANDA PB, O'KIRWAN F, WHITBY R, LIANG L, COHEN P, BHASIN S, KRAUSS RM, VELDHUIS JD, WAGNER AJ, DEPAOLI AM, MCCANN SM, WONG ML: Phenotypic effects of leptin replacement of morbid obesity, diabetes mellitus, hypogonadism and behavior in leptin-deficient adults. Proc Natl Acad Sci USA 101: 4531-4536, 2004.

LINDI V, SIVENIUS K, NISKANEN L, LAAKSO M, UUSITUPA MI: Effect of the Pro12Ala polymorphism of the PPAR-gamma2 gene on long-term weight change in Finnish non-diabetic subjects. Diabetologia 44: 925-926, 2001.

LOOS RJ, BOUCHARD C: Obesity: is it a genetic disorder? J Int Med 254: 401-425, 2003.

MAMMES O, BETOULLE D, AUBERT R, GIRAUD V, TUZET S, PETIET A, COLAS-LINHART N, FUMERON F: Novel polymorphism in the $5^{\prime}$ region of the LEP gene: association with leptin levels and response to lowcalorie diet in human obesity. Diabetes 47: 487-489, 1998.

MAMMES O, AUBERT R, BETOULLE D, PÉAN F, HERBETH B, VISVIKIS S, SIEST G, FUMERON F: Leptin receptor gene polymorphisms: associations with overweight, fat mass and response to diet in women. Eur J Clin Invest 31: 398-404, 2001.

MASUO K, KATSUYA T, KAWAGUCHI H, FU Y, RAKUGI H, OGIHARA T, TUCK ML: Rebound weight gain as associated with high plasma norepinephrine levels that are mediated through polymorphisms in the beta2adrenoceptor. Am J Hypertens 18: 1508-1516, 2005.

MORENO-ALIAGA MJ, SANTOS JL, MARTI A, MARTINEZ JA: Does weight loss prognosis depend on genetic make-up? Obes Rev 6: 155-168, 2005.

MOTTAGUI-TABAR S, RYDÉN M, LOFGREN P, FAULDS G, HOFFSTEDT J, BROOKES AJ, ANDERSSON I, ARNER P: Evidence for an important role of perilipin in the regulation of human adipocyte lipolysis. Diabetologia 46: 789-797, 2003.

NAKAMURA M, TANAKA M, ABE S, ITOH K, IMAI K, MASUDA T, NAKAO H: Association between beta-3adrenergic receptor polymorphism and a lower reduction in the ratio of visceral fat to subcutaneous fat area during weight loss in Japanese obese women. Nutr Res 20: 25-34, 2000.

NASLUND E, ANDERSSON I, DEGERBLAD M, KOGNER P, KRAL JG, ROSSNER S, HELLSTROM PM: Associations of leptin, insulin resistance and thyroid function with long-term weight loss in dieting men. J Intern Med 248: 299-308, 2000.

NICKLAS BJ, VAN ROSSUM EF, BERMAN DM, RYAN AS, DENNIS KE, SHULINDER AR: Genetic variation in the peroxisome proliferator-activated receptor-gamma2 gene (Pro12Ala) affects metabolic responses to weight loss and subsequent weight regain. Diabetes 50: 2172-2176, 2001. 
OEFFNER F, BORNHOLDT D, ZIEGLER A, HINNEY A, GORG T, GERBER G, GOLDSCHMIDT HP, SIEGFRIED W, WRIGHT A, HEBEBRAND J, GRZESCHIK KH: Significant association between a silent polymorphism in the neuromedin B gene and body weight in German children and adolscents. Acta Diabetol 37: 93-101, 2000.

O'RAHILLY S, FAROOQI S, YEO GHS, CHALLIS BG: Minireview: Human obesity lessons from monogenic disorders. Endocrinology 144: 3757-3764, 2003.

PETERS WR, MACMURRY JP, WALKER J, GIESE RJ JR, COMINGS DE: Phenylethanolamine Nmethyltransferase G-148A genetic variant and weight loss in obese women. Obes Res 11: 415-419, 2003.

POOLEY EC, FAIRBURN CG, COOPER Z, SODHI MS, COWEN PJ, HARRISON PJ: A 5-HT $2 \mathrm{C}$ receptor promoter polymorphism (HTR2C $-759 \mathrm{C} / \mathrm{T}$ ) is associated with obesity in women, and with resistance to weight loss in heterozygotes. Am J Med Genet 126B: 124-127, 2004.

POTOCZNA N, WERTLI M, STEFFEN R, RICKLIN T, LENTES KU, HORBER FF: G protein polymorphisms do not predict weight loss and improvement of hypertension in severely obese patients. $J$ Gastrointest Surg $\mathbf{8}$ : 862-868, 2004.

QI L, SHEN H, LARSON I, SCHAEFER EJ, GREENBERG AS, TREGOUET DA, CORELLA D, ORDOVAS JM: Gender-specific association of a perilipin gene haplotype with obesity risk in a white population. Obes Res 12: 1758-1765, 2004.

RANKINEN T, ZUBERI A, CHAGNON YC, WEISNAGEL SJ, ARGYROPOULOS G, WALTS B, PÉRUSSE L, BOUCHARD C: The human obesity gene map: the 2005 update. Obesity 14: 529-644, 2006.

RAWSON ES, NOLAN A, SILVER K, SHULDINER AR, POEHLMAN ET: No effect of the Trp64Arg beta(3)adrenoreceptor gene variant on weight loss, body composition, or energy expenditure in obese, caucasian postmenospausal women. Metabolism 51: 801-805, 2002.

REINEHR T, HINNEY A, NGUYEN TT, HEBEBRAND J: Evidence of an influence of a polymorphism near the INSIG2 on weight loss during a lifestyle intervention in obese children and adolescents. Diabetes (In press) 2007.

RUANO G, WINDEMUTH A, KOCHERLA M, HOLFORD T, FERNANDEZ ML, FORSYTHE CE, WOOD RJ, KRAEMER WJ, VOLEK JS: Physiogenomic analysis of weight loss induced by dietary carbohydrate restriction. Nutr Metab (London) 3: 20, 2006.

RUSHING PA, GIBBS J, GEARY N: Brief, meal-contingent infusions of gastrin-releasing peptide 1-27 and neuromedin B-10 inhibit spontaneous feeding in rats. Physiol Behav 60: 1501-1504, 1996.

SAKANE N, YOSHIDA T, UMEKAWA T, KOGURE A, TAKAKURA Y, KONDO M.: Effects of Trp64Arg mutation in the beta-3 adrenergic receptor gene on weight loss, body fat distribution, glycemic kontrol, and insulin resistence in obese type 2 diabetic patiens. Diabetes Care 20: 1887-1890, 1997.

SANTORO N, PERRONE L, CIRILLO G, RAIMONDO P, AMATO A, COPPOLA F, D'ANIELLO A, MIRAGLIA DEL GIUDICE E: Weight loss in obese children carrying the proopiomelanocortin R236G variant. $J$ Endocrinol Invest 29: 226-230, 2006.

SANTORO N, PERRONE L, CIRILLO G, RAIMONDO P, AMATO A, BRIENZA C, DEL GIUDICE EM: Effect of the melanocortin-3 receptor C17A and G241A variants on weight loss in childhood obesity. Am J Clin Nutr 85: 950-953, 2007.

SCUTERI A, SANNA S, CHEN WM, UDA M, ALBAI G, STRAIT J, NAJJAR S, NAGARAJA R, ORRU M, USALA G, DEI M, LAI S, MASCHIO A, BUSONERO F, MULAS A, EHRET GB, FINK AA, WEDER AB, COOPER RS, GALAN P, CHAKRAVARTI A, SCHLESSINGER D, CAO A, LAKATTA E, ABECASIS GR: Genome-wide association scan shows genetic variants in the FTO gene are associated with obesity-related traits. PLoS Genet 3: e115, 2007.

SEIDELL JC: Prevalence and time trends of obesity in Europe. J Endocrinol Invest 25: 816-822, 2002.

SESTI G, PEREGO L, CARDELLINI M, ANDREOZZI F, RISCALI C, VEDANI P, GUZZI V, MARCHI M, PAGANELLI M, FERLA G, PONTIROLI AE, HRIBAL ML, FOLLI F: Impact of common polymorphisms in candidate genes for insulin resistance and obesity on weight loss of morbidly obese subjects after laparoscopic adjustable gastric banding and hypocaloric diet. J Clin Endocrinol Metab 90: 5064-5069, 2005. 
SHIMIZU H, MORI M: Trp64Arg mutation of beta 3-adrenergic receptor gene determines weight losing effect of mazindol. Obes Res 12 (Oct Suppl): A37, 2004.

SHIN HD, KIM KS, CHA MH, YOON Y: The effects of UCP-1 polymorphisms on obesity phenotypes among Korean female subjects. Biochem Biophys Res Commun 335: 624-630, 2005.

SHIWAKU K, NOGI A, ANUURAD E, KITAJIMA K, KITAJIMA K, ENKHMAA B, SHIMONO K, YAMANE Y: Difficulty in losing weight by behavioral intervention for women with Trp64Arg polymorphism of the beta-3 adrenergic receptor gene. Int J Obes Relat Metab Disord 27: 1028-1036, 2003.

SOOKOIAN S, GEMMA C, GARCÍA SI, GIANOTTI TF, DIEUZEIDE G, ROUSSOS A, TONIETTI M, TRIFONE L, KANEVSKY D, GONZÁLES CD, PIROLA CJ: Short allele of serotonin transporter gene promoter is a risk factor for obesity in adolescents. Obesity 15: 271-276, 2007.

SØRENSEN TI, BOUTIN P, TAYLOR MA, LARSEN LH, VERDICH C, PETERSEN L, HOLST C, ECHWALD SM, DINA C, TOUBRO S, PETERSEN M, POLAK J, CLÉMENT K, MARTÍNEZ JA, LANGIN D, OPPERT JM, STICH V, MACDONALD I, ARNER P, SARIS WH, PEDERSEN O, ASTRUP A, FROGUEL P; NUGENOB Consortium: Genetic polymorphisms and weight loss in obesity: a randomised trial of hypo-energetic highversus low-fat diets. PLoS Clin Trials 1: e12, 2006.

SPÁLOVÁ J, ZAMRAZILOVÁ H, VČELÁK J, VAŇKOVÁ M, LUKÁŠOVÁ P, HILL M, HLAVATÁ K, ŠRÁMKOVÁ P, FRIED M, ALDHOON B, KUNEŠOVÁ M, BENDLOVÁ B, HAINER V: Neuromedin beta: P73T polymorphism in overweight and obese subjects. Phys Res 57 (Suppl 1): S39-S48, 2008.

STEFANSKI A, MAJKOWSKA L, CIECHANOWCZ A, FRANKOW M, SAFRANOW K, PARCZEWSKI M, PILARSKA K: Lack of association between the Pro12Ala polymorphism in PPAR-gamma2 gene and body weight changes, insulin resistance and chronic diabetic complications in obese patients with type 2 diabetes. Arch Med Res 37: 736-743, 2006.

STEINLE NI, HSUEH WC, SNITKER S, POLLIN TI, SAKUL H, ST JEAN PL, BELL CJ, MITCHELL BD, SHULDINER AR: Eating behavior in the Old Order Amish: heritability analysis and a genome-wide linkage analysis. Am J Clin Nutr 75: 1098-1106, 2002.

STUNKARD AJ, MESSICK SM: The three-factor eating questionnaire to measure dietary restraint, disinhibition and hunger. $J$ Psychosom Res 29: 71-83, 1985.

STUNKARD AJ, HARRIS JR, PEDERSEN NL: The body mass index of twins who have been reared apart. $N$ Engl $J$ Med 322: 1483-1487, 1990.

TCHERNOF A, STARLING RD, TURNER A, SHULDINER AR, WALSTON JD, SILVER K, POEHLMAN ET: Impaired capacity to lose visceral adipose tissue during weight reduction in obese postmenopausal women with the Trp64Arg beta3-adrenoceptor gene variant. Diabetes 49: 1709-1713, 2000.

THOLIN S, RASMUSSEN F, TYNELIUS P, KARLSSON J: Genetic and environmental influences on eating behavior: the Swedish young male twins study. Am J Clin Nutr 81: 564-569, 2005.

TOUBRO S, SØRENSEN TIA, HINDSBERGER C, CHRISTENSEN NJ, ASTRUP A: Twenty-four-hour respiratory quotient: The role of diet and familial resemblance. J Clin Endocrinol Metab 83: 2758-2764, 1998.

TWOROGER SS, CHUBAK J, AIELLO EJ, YASUI Y, ULRICH CM, FARIN FM, STAPLETON PL, IRWIN ML, POTTER JD, SCHWARTZ RS, MCTIERNAN A: The effect of CYP19 and COMT polymorphisms on exercise-induced fat loss in postmenopausal women. Obes Res 12: 972-981, 2004.

VAISSE G, CLEMENT K, GUY-GRAND B, FROGUEL P: A frameshift mutation in human MC4R is associated with dominant form of obesity. Nat Genet 20: 113-114, 1998.

VAZQUEZ ROQUE MI, CAMILLERI M, CLARK MM, TEPOEL DA, JENSEN MD, GRASZER KM, KALSY SA, BURTON DD, BAXTER KL, ZINSMEISTER AR: Alteration of gastric functions and candidate genes associated with weight reduction in response to sibutramine. Clin Gastroenterol Hepatol 5: 829-837, 2007.

VERDICH C, TOUBRO S, BUEMANN B, HOLST JJ, BULOW J, SIMONSEN L, SONDERGAARD SB, CHRISTIANSEN NJ, ASTRUP A: Leptin levels are associated with fat oxidation and dietary-induced weight loss in obesity. Obes Res 9: 452-461, 2001.

VIGUERIE N, POITOU C, CANCELLO R, STICH V, CLÉMENT K, LANGIN D: Transcriptomics applied to obesity and caloric restriction. Biochimie 87: 117-123, 2005a. 
VIGUERIE N, VIDAL H, ARNER P, HOLST C, VERDICH C, AVIZOU S, ASTRUP A, SARIS WH, MACDONALD IA, KLIMCAKOVA E, CLÉMENT K, MARTINEZ A, HOFFSTEDT J, SØRENSEN TI, LANGIN D: Nutrient-gene interactions in human obesity--implications for dietary guideline (NUGENOB) project: Adipose tissue gene expression in obese subjects during low-fat and high-fat hypocaloric diets. Diabetologia 48: 123$131,2005 b$.

VOGELS N, MARIMAN EC, BOUWMAN FG, KESTER AD, DIEPVENS K, WESTERTERP-PLANTENGA MS: Relation of weight maintenance and dietary restraint to peroxisome proliferator-activated receptor gamma2, glucocorticoid receptor, and ciliary neurotrophic factor polymorphisms. Am J Clin Nutr 82: 740-746, 2005.

WESTBERG L, BAH J, RASTAM M, GILLBERG C, WENTZ E, MELKE J, HELLSTRAND M, ERIKSSON E: Association between a polymorphism of the 5- $\mathrm{HT}_{2 \mathrm{C}}$ receptor and weight loss in teenage girls. Neuropsychopharmacology 26: 789-793, 2002.

WHO: Obesity: preventing and managing the global epidemic. WHO Technical Report Series No. 894. World Health Organization, Geneva. November, 2000.

WHO: Prevalence of excess body weight and obesity in children and adolescents. Fact Sheet No. 2.3, May 2007. Www.euro.who.int

XINLI W, XIAOMEI T, MEIHUA P, SONG L. Association of a mutation in the beta3-adrenergic receptor gene with obesity and response to dietary intervention in Chinese children. Acta Paediatr 90: 1233-1237, 2001.

YOON Y, PARK BL, CHA MH, KIM KS, CHEONG HS, CHOI YH, SHIN HD: Effects of genetic polymorphisms of UCP2 and UCP3 on very low calorie diet-induced body fat reduction in Korean female subjects. Biochem Biophys Res Commun 359: 451-456, 2007.

YOSHIDA T, SEKANE N, UMEKAWA T, SAKAI M, TAKAHASHI T, KONDO M: Mutation of beta 3-adrenergicreceptor gene and response to treatment of obesity. Lancet 346: 1433-1434, 1995. 